\title{
Pembinaan Masyarakat Islam Melalui Pendekatan Dzikir dan Pikir Studi Pada Majlis Ta'lim Ar-Rahman RT 17 Desa Way Huwi Kecamatan Jatiagung Lampung Selatan
}

\author{
Yahya AD \\ Universitas Islam Negeri Raden Intan Lampung
}

Diterima: Juni 2017. Disetujui: Oktober 2017. Dipublikasikan: Desember 2017

\begin{abstract}
Based on the National Survey of BNPT November 2017, the potential for radicalism in Lampung Province reached $58.38 \%$. The increasingly widespread days of violence, both in the household and community, whether on a small scale or a particular community, or large scale such as between villages, between villages, even between subdistricts involving ethnic and religious elements. Majlis Ta'lim Ar-Rahman in the guidance of the community in RT. 17 Village Way Huwi District Jatiagung Lampung Selatan interesting to investigate, because the coaching system that combines the development of thought and dhikr. The development of thought aspect through the study of Islamic material systematically according to its scope, then applied it through amaliah dhikr by tasawuf-tarekat method. To describe how the implementation of coaching is applied and what kind of picture of religious experience experienced by members or jama'ahnya then this study using the approach of Islamic sciences and psychology, especially Islamic psychology (Sufi psychology), with descriptive qualitative method. Based on in-depth interviews with participant observation it can be concluded that coaching through dhikr approach and thought is able to develop society toward religious transformation.
\end{abstract}

Keywords : Guidance; Islamic; society; dhikr; approach

\begin{abstract}
Abstrak: Berdasarkan hasil survei nasional BNPT Nopember 2017, potensi radikalisme di Provinsi Lampung mencapai 58,38\%. Kian hari kian marak terjadi tindak kekerasan, baik di lingkungan rumah tangga maupun masyarakat, baik dalam skala kecil atau komunitas tertentu, maupun skala besar seperti antar kampung, antar desa, bahkan antar kecamatan yang melibatkan elemen suku mapun agama. Majlis Ta'lim Ar-Rahman dalam pembinaan terhadap masyarakat di RT. 17 Desa Way Huwi Kecamatan Jatiagung Lampung Selatan menarik untuk diteliti, karena sistem pembinaan yang dilakukan menggabungkan antara pengembangan pikir dan dzikir. Pengembangan aspek pikir melalui pengkajian materi-materi keislaman secara sitematis menurut ruanglingkupnya, kemudian diaplikasinya melalui amaliah dzikir dengan metode tasawuf-tarekat. Untuk mendeskripsikan bagaimana implementasi pembinaan yang diterapkan dan seperti apa gambaran pengalaman religius yang dialami oleh anggota atau jama'ahnya maka penelitian ini menggunakan pendekatan ilmu-ilmu keislaman dan psikologi, terutama psikologi Islami (psikologi sufi), dengan metode kualitatif deskriptif. Berdasarkan wawancara secara mendalam disertai observasi partisipan dapat disimpulkan bahwa pembinaan melalui pendekatan dzikir dan pikir mampu mengembangkan masyarakat menuju transformasi religius.
\end{abstract}

Kata Kunci : Pembinaan; masyarakat; Islam; pendekatan; dzikir

\section{Pendahuluan}

Berbicara tentang masyarakat mau tidak mau, suka tidak suka kita berhadapan dengan yang namanya manusia, baik secara personal maupun dalam bentuk komunal. Sedangkan manusia sebagai personal merupakan ciptaan Allah yang paling indah dan paling tinggi derajadnya. Manusia dicipatakan oleh Allah dengan membawa misi mulia sebagai khalifah di muka bumi. Predikat "paling indah" dan "paling tinggi atau paling mulia" dapat diartikan bahwa manusia adalah satu-satunya makhluk Allah yang mampu mendatangkan kesenangan, ketenangan, kedamaian dan kebahagiaan di mana pun dan pada saat apa pun, baik bagi dirinya maupun bagi makhluk lain di sekitarnya.

Keindahan dan kemuliaan manusia berpangkal pada diri manusia itu sendiri. Indah secara fisik karena memiliki piranti dan kelengkapan seperti pancaindra, mulut, tangan, kaki, otak dan 
lain sebagainya(Prayitno \& Errman, 1999). Indah secara psikhis karena manusia dikaruniai kelengkapan fungsi mental dan spiritual yang luar biasa seperti kemampuan berpikir, berkeyakinan, mencipta, berintrospeksi, bertenggang rasa, dan masih banyak lagi potensi-potensi lainnya. Apabila seluruh potensi yang dimiliki manusia itu dikembangkan serta difungsikan secara optimal, maka manusia akan mampu meraih taraf hidup yang sangat layak, mampu mengembangkan ilmu pengetahuan, teknologi, dan peradaban modern. Namun secara historis dan faktual kita menyaksikan bahwa setinggi apa-pun kemajuan ilmu pengetahuan dan teknologi yang berhasil dicapai oleh manusia tidak menjamin akan terwujudnya kedamaian dan kebahagiaan seperti yang didambakan. Semua kemajuan yang telah dicapai itu ternyata tidak cukup membawa mansuai menajalani kehidupannya dengan kesenangan dan kebahagiaan. Berbagai ancaman dan kesengsaraan selalu membayangi perjalanan hidup manusia, bahkan bisa jadi tidak akan terelakkan jika manusia lengah dan lupa terhadap hakikat penciptaannya, yaitu meraih kemajuan ilmu pengetahuan dan teknologi setinggi mungkin demi kemaslahatan umat manusia serta makhluk lainnya dan sekaligus sebagai sarana ibadah, sebagai fungsi kekhalifahannya.

Salah satu damapak nyata abad millennium ketiga adalah meningkatnya kebutuhan dan keinginan manusia atau masyarakat untuk memperoleh kemewahan hidup, karena mereka menganggap kemewahan sebagai indikator kesenangan dan kebahagiaan. Pandangan seperti ini membuat kehidupan semakin kompetetitif dan membuka peluang bagi manusia untuk berjuang mencapai status dan tingkat kehidupan yang lebih baik. Sebagai dampak positif dari kondisi abad millennium adalah semakin meningkatnya motivasi manusia untuk terus berpikir dan berusaha meningkatkan kemampuan di berbagai bidang, dan seolah tidak pernah puas terhadap apa yang telah dicapai saat ini.

Disamping dampak positifnya, juga yang tidak kalah pentingnya untuk diwaspadai adalah damapak negatif abad ini adalah: 1) munculnya keresahan hidup di tengah masyarakat akibat dari berbagai konflik kepentingan, sehingga tidak jarang menimbulkan stress, kecemasan yang tak berujung, dan akhirnya prustasi; 2) akibat tekanan hidup yang semakin berat dan persaingan semakin meningkat, maka lahirlah kecenderungan sikap dan pola hidup yang tidak disiplin, abai terhadap nilai-nilai luhur dan norma sosial maupun, semakin subur kolusi, korupsi, dan nepotisme, ukuran baik-buruk, benar-salah, etis-tidak etis semakin kabur; 3) dalam situasi persaingan hidup semakin tinggi, muncullah kelompok-kelompok yang ambisius memaksakan kehendak, akibatnya timbul konflik yang berakibat pada korban jiwa dan harta; 4) munculnya kecenderungan menghindari konflik dengan jalan pintas yang bersifat sementara dan adiktif (narkoba); 5) akumulasi dari semua gejala tersebut akan melahirkan orang atau kelompok yang memilki sikap radikalisme, terorisme, intoleransi dan berbagai yang meresahkan kehidupan masyarakat, sebagaimana fenomena yang terjadi akhir-akhir ini.

Sikap dan perilaku radikal, teror dan bentuk-bentuk kekerasan lainnya tidak khas milik salah satu golongan maupun agama, karena semua suku, bangsa, dan penganut agama manapun serta dimana pun bisa terjadi. Oleh sebab itu patut disayangkan dan dipertanyakan adanya ketidak adilan dalam pemberitaan media massa yang terjadi dewasa ini, dimana sikap dan perilaku radikalisme - terorisme seolah-olah hanya disematkan kepada kelompok yang beragama Islam. Sementara disisi lain apabila kelompok non-muslim yang melakukan tindak kekerasan terhadap masyarakat banyak, hanya disebut kelompok keriminal bersenjata (KKB), meskipun sudah jelasjelas melakukan terror dan kejahatan kemanusiaan. Apa yang terjadi di Jawa Barat di akhir tahun 2016 lalu, adanya salah satu kelompok organisasi massa bentukan dadakan, melakukan penyerangan terhadap kelompok FPI, oleh media hanya disebut "bentrokan". Sebaliknya apabila 
kelompok FPI yang memulai bentrokan, maka beritanya yang muncul adalah "penyerangan", bahkan cenderung dibesar-besarkan.

Dilihat dari latar belakang dan motifnya bisa bermaca-macam. Namun dari gejala yang nampak paling tidak ada dua hal yang menjadi faktor penyebabnya, yaitu: unsur ketidak adilan yang memicu ketidak puasan dan pemahaman terhadap ajaran agama yang keliru. Akibatnya agama dan pemeluk agama menjadi tertuduh atau bahkan terdakwa sebagai sumber pemicu timbulnya radikalisme. Pertanyaannya kemudian, sudah sekejam itukah sikap dan perilaku manusia? Apakah sikap dan perilaku tersebut berlaku secara umum ataukah kasuistis saja? Apakah agama sudah kehilangan fungsi kontrolnya? lalu dimana letak daya tangkal agama terhadap kemungkaran, daya perekat dan pemersatu, serta fungsi edukasi dan pencerahan agama guna mewujudkan "kahira ummah"?

Terlepas faktor apa yang melatar belakangi maraknya sikap dan perilaku radikal yang ditampilkan oleh sebagian orang, namun sebagai umat Islam sudah menjadi kewajiban, bahkan sebagian ulama menyatakan hukumnya "fardhu 'ain" mempelajari syari'at Islam secara baik dan benar. Hal ini bukan saja untuk kemaslahatan dan keselamatan bagi dirinya, tapi juga bagi keluarganya, masyarakat, dan bangsa pada umumnya. Di sinilah pentingya upaya pembinaan dilakukan guna mencerdaskan masyarakat, baik secara intelektual, emosional, maupun spiritual, sehingga benar-benar layak menyandang predikat "Khaira Ummah" atau sebagai umat yang terbaik.

Apa yang dilakukan oleh Majlis Ta'lim Ar-Rahman dalam pembinaan terhadap masyarakat di RT. 17 Desa Way Huwi Kecamatan Jatiagung Lampung Selatan, patut diapresiasi. Untuk mengetahui apa saja program pembinaan yang dilakukan dan bagaimana implementasinya, diperlukan penelitian dengan judul: "Pembinaan Masyarakat Islam Melalui Pendekatan Dzikir dan Pikir (Studi pada Majlis Ta'lim Ar-Rahman RT 17 Desa Way Huwi Kecamatan Jatiagung Lampung Selatan)'.

Masalah yang menjadi bahan telaahan dalam penelitian ini adalah "bagaimanakah implementasi pembinaan masyarakat Islam melalui pendekatan dzikir dan pikir yang diterapkan pada Majlis Ta'lim Ar-Rahman Desa Way Huwi Lampung Selatan?" Agar penelitian ini lebih terarah, maka fokus penelitian lebih diperjelas dengan beberapa pertanyaan penelitian sebagai berikut (1) Bagaimanakah konsep dan implementasi dzikir dan pikir perspektif Al-Qur'an dan Sunnah ? , (2) Bagaimanakah pola pembinaan masyarakat Islam melalui implementasi dzikir dan pikir yang diterapkan oleh Majlis Ta'lim Ar-Rahman RT 17 Way Huwi Jatiagung Lampung Selatan ?, (3) Bagaimanakah gambaran pengalaman religius yang dirasakan oleh para partisipan setelah mengikuti proses pembinaan tersebut ?. Tujuana dari penelitian ini adalah (a) mendeskripsikan konsep serta implementasi dzikir dan pikir perspektif Al-Qur'an dan Sunnah, (b) mendeskripsikan pola pembinaan masyarakat Islam melalui implementasi dzikir dan pikir yang diterapkan oleh Majlis Ta'lim Ar-Rahman RT 17 Way Huwi Jatiagung Lampung Selatan. (c) mendeskripsikan pengalaman religius partisipan setelah mengikuti amaliah dzikir dan pikir.

\section{Metode Penelitian}

Penelitian ini termasuk ke dalam penelitian deskriptif kualitatif dengan menggunakan tekhnik Purposive sampling karena peneliti menentukan pengambilan sampel dengan cara menetapkan ciri-ciri khusus yang sesuai dengan tujuan penelitian sehingga diharapkan dapat menjawab permasalahan yang menjadi fokus penelitian untuk menggambarkan situasi sosial (populasi) meliputi: tempat (place), pelaku (actor), dan aktivitas (activity)(Sugiyono, 2012). Purposive sampling adalah teknik mengambilan sampel penelitian dengan tidak berdasarkan 
random, daerah atau strata, melainkan berdasarkan atas adanya pertimbangan yang berfokus pada tujuan tertentu(Arikunto, 2006), Beberapa karakteristik sampel purposive sifatnya: 1) sementara (emergent), 2) menggelinding seperti bola salju (snowball), 3) disesuaikan dengan kebutuhan (continuous adjustment), dan 4) dipilih sampai jenuh (selection to the point of redundancy)(Sugiyono, 2016).

Meskipun hasil penelitian kualitatif tidak bisa digeneralisasi ke populasi, kecuali hanya berlaku untuk situasi sosial yang menjadi fokus penelitian, namun hasilnya dapat ditransferkan atau diterapkan ke situasi soisal di tempat lain apabila situasi sosialnya memiliki kemiripan atau kesamaan dengan situasi sosial yang diteliti.

Atas dasar pertimbangan itu maka yang dijadikan sampel dalam penelitian ini adalah jamaah yang secara rutin dan aktif mengikuti ta'lim serta pengamalan dzikir secara rutin, baik shalat sendiri maupun berjamaah di Masjid ar-Rahaman Way Huwi Kabupaten Lampung Selatan. Sedangkan ciri khusus yang menjadi kriteri dalam penelitian adalah a) jama'ah yang secaraaktif mengikuti pengajian (pendalaman materi) dan amaliah dzikir, b) jama'ah yang secara rutin mengamalkan amaliah dzikir, baik secara berjama'ah di masjid maupun sendiri-sendiri, c) jangka waktu keikutsertaannya serta pengamalannya minimal satu tahun.

Sumber primer adalah sumber-sumber yang memberikan data secara langsung dari tangan pertama atau merupakan sumber asli(Nasution, 2001). Sumber primer dalam penelitian ini adalah al-Qur'an dan Hadits serta beberapa orang jama'ah majlis ta'lim Ar-Rahman yang menjadi partisipan atau narasumber. Sumber sekunder adalah sumber-sumber yang diambil dari sumber lain yang tidak diperoleh dari sumber primer. Sumber sekunder yang dimaksud adalah buku-buku yang berhubungan dengan permasalahan yang menjadi fokus bahasan(Anwar, 1998). Selain buku, juga jurnal dan hasil penelitian yang berkaitan dengan dzikir dan pikir. Demikian juga buku-buku yang membahas tentang teori-teori yang berkaitan dengan masalah pendidikan akal dan hati serta pendapat para ahli dijadikan sebagai sumber skunder.

Teknik pengumpulan data menggunakan setting alamiah (natural setting), yaitu dengan mengundang berbagai responden dalam pertemuan untuk memperoleh data primer melalui wawancara mendalam semi terstruktur, yang pelaksanaannya lebih bebas. Di sini pewawancara mengajukan pertanyaan-pertanyaan tanpa dipersiapkan alternative jawaban. Alat-alat wawancara yang digunakan antara lain: buku catatan, tape recorder, dan camera. Selain teknik wawancara peneliti juga menggunakan observasi partisipan dengan cara ikut serta dalam komunitas pada saat shalat dan dzikir berjama'ah di masjid. Data dokumentasi diperoleh dalam bentuk SK dan Struktur organisasi, visi, misi, dan tujuan, serta program dan target capaian. Untuk menjamin keabsahan data yang diperoleh, dilakukan triangulasi. Baik triangulasi teknik dengan observasi partisipan serta wawncara mendalam, dan triangulasi sumber dengan cara mencari informasi dari sumber yang berbeda.

Analisis data menggunakan model Miles dan Huberman, yang dimulai semenjak proses pengumpulan data berlangsung, dan setelah pengumpulan data selesai pada periode tertentu. Tahapan analisis dimulai sejak proses wawancara dimulai dan berlangsung secara interaktif sampai tuntas. Apabila jawaban yang diberikan dianggap masih kurang memuaskan, maka wawancara dilanjutkan lagi sampai pada tahap tertentu, dimana data yang diperoleh sudah dianggap kredibel.

Data yang diperoleh akan disusun dalam bentuk uraian yang sangat lengkap dan banyak. Data yang telah diperoleh melalui wawancara dan observasi, kemudian dirangkum dan dipilah serta dipilih hal-hal yang pokok, lalu difokuskan pada hal-hal yang penting serta dicari tema dan polanya. Dengan demikian, data yang telah direduksi dan diberi kode-kode tertentu akan 
memberikan gambaran yang lebih jelas, dan memudahkan peneliti untuk melakukan pengumpulan data selanjutnya apabila diperlukan. Penyajian data dilakukan dalam bentuk uraian atau teks yang bersifat naratif singkat dan bagan atau tabel yang berkaitan dengan kategorikategori tertentu yang sejenis. Data yang sudah didisplaykan akan memudahkan untuk memahami apa yang sebenarnya yang terjadi, lalu dilakukan perencanaan selanjutnya berdasarkan pemahaman tersebut. Sebagai langkah terakhir adalah penarikan kesimpulan sebagai jawaban dari perumusan masalah yang dirumuskan sejak awal penelitan yang berupa deskripsi atau gambaran suatu objek yang sebelumnya masih belum jelas dan setelah diteliti menjadi jelas(Sugiono, 2009). Hasil temuan penelitian ini akan diuraikan sebagai berikut:

\section{Hasil dan Pembahasan}

Hasil Penelitian yang berhasil digali melalui wawancara dan observasi partisipan pada jama'ah Majslis Ta'lim Ar-Rahman RT 17 Desa Way Huwi, terungkap bahwa pembinaan masyarakat Islam yang dilakukan dengan pola pendekatan integratif, terprogram, sitematis, intensif dan kontinyu, ternyata mampu merubah mindset serta perilaku secara personal maupun komunal. Hal ini terungkap melalui wawancara bahwa berbagai manfaat yang mereka rasakan setelah mengikuti pengkajian keislaman (Pembinaan aspek pikir) secara sistematis mampu merubah antara lain:

a. Partisipan merasakan wawasan keislamannya semakin luas, pengetahuan dan pemahaman tentang agama Islam bertambah, dan pada gilirannya menjadi semakin dewasa menyikapi perbedaan. Semula melihat orang yang berbeda paham dan aliran, dianggap sebagai musuh dalam selimut, ada rasa curiga bahkan ada yang menganggapnya sebagai lawan atau saingan, karena merasa hanya golongan mereka saja yang termasuk umat yang selamat sedangkan golongan lain adalah pengikut aliran-aliran sesat. Namun setelah dikaji secara historis-teologis, partisipan menyadari bahwa ternyata mereka sama-sama Ahlusunnah Waljama'ah (ASWAJA).

b. Terjadi perubahan pola pikir dan sikap mereka dari rasa curiga, bahkan rasa benci dan bermusuhan terhadap orang atau kelompok yang berbeda paham dan cara pengamalan ibadah, menjadi positif thinking karena sudah memahami posisi dan latar belakang mengapa terdapat banyak firqah, paham (mazhab), dan juga berbagai macam tarekat dalam Islam. Melalui pengkajian tentang ajaran Islam secara benar, terprogram, dan sistematis, kecerdasan masyarakat dapat ditingkatkan secara bertahap, baik kecerdasan intelektual, emosional, maupun spiritualnya.

c. Terjadi perubahan pola keyakinan atau kemantapan dalam beribadah, dari adanya unsur karagu-raguan atau penyakit was-was dalam beribadah, menjadi lebih yakin dan mantap karena telah memahami dasar hukum serta adanya berbagai penafsiran serta argumentasinya masing-masing. Melalui pengkajian tentang fikih dan tauhid yang menjadi pegangan Ahlusunnah Wal Jama'ah, sedikit demi sedikit paham dan tradisi yang selama ini mereka anggap benar tanpa dasar dalil yang jelas kalau itu bersumber dari ajaran Islam, mulai dihindari.

d. Terjadi perubahan pola sikap dari merasa kurang nyaman bergaul dengan komunitas yang berbeda (SARA), menjadi rasa damai hidup berdampingan dengan berbagai suku dan agama atau paham sepanjang tidak saling mengganggu. Hal ini bisa terjadi karena mereka sudah memiliki konsep tentang identitas diri sebagai umat Islam sudah semakin jelas dan sudah 
mengerti bagaimana seharusnya merespon dan menyiapi perbedaan serta kemajemukan dalam masyarakat.

e. Melahirkan kecerdasan sosial dari kurang peduli dengan kebersamaan menjadi lebih peka dan rasa empati terhadap kesulitan penderitaan orang lain, muncul rasa senasib sepenanggungan. Hal ini terlihat jika ada warga yang sakit, mereka secara bersama sama mendo'akan lalu membesuk secara bersama pula.

Adapun hasil yang dicapai dari aspek pengamalan dzikir antara lain:

a. Partisipan merasa menemukan ketenangan batin dan merasakan nikmatnya ibadah sebagai sebuah kebutuhan primer, sehingga merasa rugi bila dalam satu waktu tidak bisa ikut shalat dan dzikir berjama'ah di masjid. Ibarat makan dan minum adalah kebutuhan jasmani, maka ibadah, terutama shalat dan dzikir adalah makanan rohani; jika jasmani memerlukan asupan makanan dan minuman tiga kali sehari, maka rohani paling tidak memerlukan asupan makanan lima kali sehari semalam. Inilah janji Allah bahwa hanya dengan dzikrullah hati menjadi tentram (Q.S. Ar-Ra'du: 28).

b. Partisipan merasakan getaran jiwa disaat melakukan dzikir sehingga menjadi pemicu semangat untuk lebih taqarrub ilallah. Hal ini bisa terjadi makala dzikir yang dilakukan dengan sepenuh jiwa. Perintah berdzikir adalah di dalam jiwa (fi nafsik) (Q.S. Al-A'raf: 205) bukan hanya sebatan ucapan lisan, melainkan harus menyentuh seluruh latifah yang ada dalam diri manusia. Karakteristik orang mukmin apabila disebut nama Allah, gemetar hatinya, dan apabila dibacakan kepadanya ayat-ayat-Nya bertambah kuat imannya dan hanya Allah mereka berserah diri. (Q.S. Al-Anfal: 2).

c. Partisipan merasa hatinya terbuka untuk menerima nasehat atau pengajaran yang baik sehingga menambah keyakinan tentang kebenaran ajaran Islam. Hal ini sejalan dengan Firman Allah (Q.S. Al-An'am: 12) bahwa siapa saja yang dihendaki Allah mendapat hidayah, pasti orang yang bersangkutan akan terbuka hatinya dan lapang dadanya menerima Islam. Sebaliknya yang Allah kehendaki sesat pasti dadanya merasa sesak, hatinya menjadi sempit untuk menerima nasehat tentang ajaran Islam, diumpamakan laksana diajak mendaki langit nan tinggi.

d. Partisipan merasa terpanggil untuk membersihkan jiwa (hati) melalui dzikrullah, karena meyakini bahwa hanya dengan dzikrullah hati akan menjadi bersih dan sehat dari berbagai jenis virus penyakit rohani seperti: pemarah, pendendam, hasad (iri \& dengki), 'ujub (suka membanggakan diri), takabbur (sombong, angkuh), riya, rakus, serakah, was-was, berputus asa, kikir/bakhil, dan hilangnya rasa malu. Keadaan jiwa seseorang akan dapat diketahui melalui sikap dan perilakunya, apakah salah satu atau bahkan beberapa dari indikator penyakit-penyakit hati tersebut di atas ada pada dirinya. Jika gejala-gejala penyakit itu terdapat dalam diri seseorang maka alat pembersihnya adalah dzikrullah. Sebagaimana ditegaskan dalam dalam hadis Nabi SAW., "bahwasanya bagi tiap-tiap sesuatu ada alat untuk mensucikannya, dan alat untuk mensucikan hati adalah dzikrullah”.

e. Salah seorang partisipan menyatakan bahwa dzikrullah adalah sarana penyerahan diri secara total kepada Allah. Hakikatnya kita sebagai hamba tidak punya apa-apa dan tidak bisa apaapa tanpa karuia cinta dan kasih sayang Allah SWT. Oleh sebab itu dengan menghayati substansi kalimat dzikir "La Ilaha Illallah" kemudian kita resapi dalam-dalam maknanya, maka seorang hamba akan merasakan seolah tenggelam ke dalam lautan ma'rifat. Kajian makna yang terkandung dalam kalimat tersebut hendaknya tidak hanya dipahami secara harfiah, karena makna sesungguhnya jauh lebih luas dan dalam dari yang dipahami secara awam selama ini. "Tidak ada Tuhan selain Allah" ini juga berarti tidak ada yang berhak 
disembah selain Allah, tidak ada yang menghidupkan dan mematikan kecuali Allah, tidak ada yang memberi riski selain Allah, tidk ada yang bisa menyelamatkan kecuali Allah, tidak ada yang sanggup memberi kebahagiaan hakiki kecuali Allah. Lebih dalam lagi, tidak ada yang wujud kecuali Allah, tidak ada yang hidup (Hayat) selain Allah, tidak ada yang Melihat (Bashar) kecuali Allah, tidak ada yang Mendengar (Sama'), tidak ada yang Berbicara (Kalam) kecuali Allah, dan seterusnya.

f. Intinya bahwa ternyata pembinaan masyarakat Islam melalui pendekatan dzikir dan pikir dengan pola program terpadu secara sistematis dan intensif, mampu merubah pola pikir (mind-set), pola sikap, dan perilaku ke arah yang lebih positif, produktif, lebih bermakna. Dengan kata lain pembinaan masyarakat Islam memerlukan perhatian dari berbagai pihak terkait dan sentuhan manajemen secara terpadu, baik dari aspek perencanaan program dan tujuan, aspek materi, narasumber yang mumpuni di bidangnya, serta pendekatan dan metode yang relevan, samapai pada target dan evaluasi program.

Apabila hal tersebut dapat dilaksnakan di masing-masing majlis ta'lim, maka ketakutan terhadap ancaman munculnya radikalisme terorisme tidak perlu lagi terjadi, karena individu-individu yang tergabung dalam sebuah komunitas sosial kemasyarakatan tersebut adalah mereka yang telah menemukan makna hidup dan hidup lebih bermakna dengan nilai-nilai ajaran Islam yang rahmatan lil'alamin. Di sinilah posisi stratetgis UIN Raden Intan Lampung sebagai lembaga Perguruan Tinggi Agama Islam yang memilki sumber daya yang sangat relevan dan dibutuhkan oleh masyarakat saat ini.

\section{Simpulan dan Saran}

Sebagaimana rumusan masalah yang diajukan pada Bab terdahulu dan berdasarkan temuan penelitian yang berhasil diungkap selama penelitian, akan diambil beberapa kesimpulan. Konsep pembinaan masyarakat Islam adalah upaya untuk melakukan pembaharuan atau penyempurnaan pengetahuan, sikap, dan perilaku sekumpulan individu yang membentuk komunitas sosial berdasarkan kesatuan agama sebagai ikatan spiritual yang menjadi nilai-nilai transcendental yang eksistensinya nyata dapat dipertanggungjawakan secara hukum. Karakteristik masyarakat Islam, idealnya ditandai oleh sifat-sifat Rabbani, insani, akhlaqi dan tawazun (seimbang). Yakni sebuah tatanan masyarakat yang menyandang predikat "khaira ummah" yang eksistensinya dilandasi oleh keimanan yang kokoh dan berorientasi pada kebaikan dunia akhirat "ta'muruna bil ma'ruf, wa tanhauna 'anil munkar" dengan mengemban misi tauhid (Q.S.3:110). Konsep dzikir dalam Al-Qur'an dan hadis adalah mengingat dan melafkan secara terus menerus salah satu atau beberapa nama atau kalimat-kalimat keagungan Allah SWT. Tujuan dan manfaatnya antara lain: sarana tazkiyah al-qalb dalam rangka taqarrub ilallah, untuk meraih keselamatan dan kebahagiaan hidup dunia dan akhrat. Konsep berpikir dalam Al-Qur'an adalah gejala jiwa insaniah yang bekerja secara dialogis dan dialektis-sistematis mengenai sesuatu objek (pengetahuan) dengan perantaraan membaca. Perintah membaca dalam Al-Qur'an sejalan dengan perintah berpikir agar manusia dapat mengetahui, memahami, meyakini, dan mengamlkan pengetahuan yang dihasilkan dari proses membaca. Objek pertama dan utama yang harus dibaca adalah diri sendiri, baru kemudian alam semesta, yakni langit dan bumi beserta isinya (Q.S.30:8). Relevan dengan atzar yang berbunyi "man 'arafa nafsahu faqad 'arafa Rabbahu". Pola integrasi dzikir dan pikir dalam pembinaan masyarakat Islam pada Majlis Ta'lim Ar-Rahman dilakukan secara terpadu, baik aspek materi keislamannya (aqidah, syari'ah 
dan akhlak (tasawuf-tarekat)) aspek pendekatan (individualitas, sosialitas, moralitas, religiusitas) dan aspek metode amaliahnya (teori dan praktik/riyadhah tarekat-sufi).Hasil pembinaan masyarakat Islam melalui pendekatan dzikir dan pikir pada Majlis Ta'lim Ar-Rahman yang berhasil direkam melalui wawancara dan observasi dapat disimpulkan bahwa telah terjadi transformasi penting sebagaimana dialami dan dirasakan oleh para partisipan, meliputi: transformasi spiritual-religious dan transformasi kesadaran diri. Dengan kata lain para partisipan telah mengalami perkembangan kehidupan spiritual-religius dibanding sebelumnya. Demikian juga terjadi transformasi kesadaran diri yang terlihat dari adanya perkembangan pemahaman partisipan mengenai diri mereka sendiri dan lingkungannya sebagaimana terungkap melalui wawancara dan observasi.

\section{Daftar Pustaka}

Anwar, S. (1998). Metodologi Penelitian. Yogyakarta: Pelajar Offset.

Arikunto, S. (2006). Dasar-dasar Evaluasi Pendidikan. Jakarta: Bumi Aksara.

Nasution. (2001). Metode Reseach Penelitian Ilmiah. Jakarta: Bumi Aksara.

Prayitno, \& Errman, A. (1999). Dasar-Dasar Bimbingan dan Konseling. Jakarta: PT. Rineka Cita.

Sugiono. (2009). Memahami Penelitian Kualitatif. Bandung: Alfabeta.

Sugiyono. (2012). Metode Penelitian Kombinasi (Mixed Methods). Bandung: Alfabeta.

Sugiyono. (2016). Metode Penelitian Kuantitatif Kualitatif dan R\&D. Bandung: CV Alfabeta. 